\title{
The Meta-Disciplinary: Capital at the Threshold of Control
}

Critical Sociology 2018, Vol. 44(I) 29-44 (c) The Author(s) 2016 Reprints and permissions: sagepub.co.uk/journalsPermissions.nav DOI: I0.1।77/08969205|6628308 journals.sagepub.com/home/crs

@AGE

\section{John Welsh}

University of Helsinki, Finland

\begin{abstract}
Discipline and Punish has been the seminal text for students of the rationality of disciplinary power. In recent years, critical scholarship has become increasingly keen to move analytically beyond the normative mode of disciplinary power. As such, D\&P is increasingly marginalized as a text, in favour of Foucault's later works. In this discursive context, this paper has a twofold aim. Firstly, I want to think through the transformations in labour control over the last 30 years of neoliberal counterrevolution in terms of the movement beyond disciplinary power. Secondly, I shall critique the autonomous and normative governmentality concept by the reinsertion of the 'genealogy of capital' in terms of the ontology of axiomatic capitalism. I shall address the undertreated genealogical movement from disciplinarity to governmentality, by arguing for something provisionally tagged meta-disciplinarity. The worth of such a move is to challenge the critical potency of the governmentality concept as is, in the belief that the 'meta-disciplinary' offers the most promising and relevant ligature from Foucault's work into Marxist scholarship on the transformations of neoliberal capitalism and the technologies of its megamachine that confronts us 40 years on.
\end{abstract}

\section{Keywords}

biopolitics, capitalist governmentality, Discipline and Punish, Foucault, Gulag, labour camp, meta-disciplinarity, society of control

\section{Introduction: Beyond Discipline}

Discipline and Punish has obviously been the seminal text for students of the rationality of disciplinary power. In recent years, Foucauldian scholarship has become increasingly keen to move intellectually beyond the disciplinary as 'a place that we have already ceased to be' by the last decade of the 20th century (Deleuze, 1992). The growing interest in the governmentality of the Collège de France lectures (Foucault, 2007, 2010) has led to a belief that 'contemporary mechanisms of government, regulation and administration must be understood as operating according to different logics than the classic "normative" mode of "disciplinary" power' (New Formations, 2014). 
This is hardly surprising given the swift intellectual dismissal of disciplinarity by Foucault and his disciples as an inexcusable continuation of the discourse of 'repression' (Behrent, 2010: 589-99; Pasquino, 1993: 79), in favour of more exploratory analyses of 'power' as 'actions upon actions' (Foucault, 2002b: 340). In their rush to promote the opportunity offered by the notion of governmental power to get beyond a ' 68 obsession with repression, Ewald, Pasquino, and others, have clearly therefore been eager to see in discipline an unambiguously oppressive and pessimistic modality and to ignore its potentiality, especially if viewed dialectically or even sublatively.

A rethinking of the relation between discipline and government seems in order. Therefore, I am chiefly concerned here with thinking through the relation between sovereignty, disciplinarity, and governmentality regarding the social metabolism of the biopolitical community. In particular, I want to rethink how disciplinarity relates to governmentality in a genealogy of power modalities, in order to apprehend critically the conditions of individual and collective reproduction in that social metabolism. I want to do this with two broad critical objects in mind: (1) to question the critical versatility and utility of the governmentality concept minus capital; and (2) to reconsider the now dominant assumption of liberation in the movement out of the disciplinary idiom into that of biopolitical government.

In this context, this analysis has emerged from a more specific and focused desire to understand the current transformations in the 'disciplinary technology of labour' (Foucault, 2003: 242), which have become so evidently enforced by neoliberal counterrevolution since the 1980s. In particular, it is with the transfiguration of academic life and labouring that I have been chiefly concerned, that is, with the new governing of academic life and its technical operative logic that seems to lie somewhere beyond the disciplinary and that is constitutive of the 'society of control' (Deleuze, 1992). I therefore am concerned simultaneously with understanding a specific phenomenon and critical object, yet through a more theoretical exploration of the relation between discipline and government in Foucault's thought and the intellectually critical aporia that has been generated around that relation.

The way I want to present this relation is through the notion of meta-disciplinarity, ${ }^{1}$ or rather 'meta-disciplinary techniques', towards the government of selves and populations in the biopolitical community. In this way, meta-disciplinarity, whilst broadly remaining within the rationality of discipline, brings out those practices and techniques that act as ligature between the docility, inertia, enclosure, of a disciplinarity seemingly without telos or aetia, and a biopolitical idiom of government predicated on an ontology of flux, mobility, and speed. This is an attempt to fill a puzzlingly unattended void between discipline and government in Foucauldian critical theorizing that increasingly denies us the tools to engage in effective daily counter-conducts. My aim is to challenge the assumption that there is no material discontinuity on the continuum of micro- and macro-physicality (Gordon, 1991: 4), whilst following the analytical proscription to consider practices as much as institutions, and to offer instead the meta-disciplinary as a decisive moment of 're-continuity' on the continuum.

For this critical theorizing of immediate and tangible conditions in the biopolitical population, upon and with which the modality of government is principally occupied, it appears necessary to reinsert something akin to that 'genealogy of capital' which Pasquale Pasquino, amongst others, has been so keen to divorce from any scrutiny of 'technologies of power' (1991: 107). It is only by returning to Discipline and Punish in light of the governmentality lectures that the meta-disciplinary can be discerned, particularly toward the end of that work, and a new agenda of resonating critique in governmentality analyses possibly be opened up. The way we tend to operate intertextually within a given corpus is either to perceive an 'anticipation' of later ideas and themes in earlier works, or to see the deficits of earlier works in light of later works (Skinner, 2002). This has led to History of Sexuality 1 rising to the position of ground-breaking pivot in the oeuvre, and Discipline 
and Punish being marginalized as a last gasp of 'the early works'. Thus we get the latent assumption that a 'linking of the "microphysics" to the "macrophysics" of power' via the 'governmentalisation of power techniques' is something that 'the problematic of discipline had sidelined' (Behrent, 2010: 600). However, I want to show how Discipline and Punish remains the vital ligature in Foucault's corpus for the drawing out of the 'meta-disciplinary', along with Psychiatric Power (2006) and the last lecture in the Society Must Be Defended series (2003).

Therefore, far from offering another addition to the almost medieval scholasticism into which Foucault studies is increasingly sliding, with its deepening seduction into the coherence of a discourse and its intellectual incests, there is a more radically immediate critical object at stake here beyond the appearance of dry academic parsing. The agenda behind this articulation of the metadisciplinary is to derive a theoretically informed, yet technical, understanding of how a disciplinary technology of labour is being transformed in terms of capitalist imperatives in the biopolitical community, and what might therefore be the most appropriate and efficacious forms of resistance and counter-conduct within it, given the rapidly dissolving critical potency of the governmentality agenda as it stands.

\section{A Meta-Disciplinary Technology of Labour?}

Questions of labour throughout the modern history of homo faber are undoubtedly bound to Foucault's 'great carceral continuum' (1991a: 297) and, as I shall argue, the one cannot be understood without consideration of the exigencies and modes of the other. At the heart of the problem of social reproduction in the materialist understanding of social metabolism lies the problem of labour, how it is obtained socially, and how it is tasked. In short, considerations of the carceral must allude somewhere to the 'disciplinary technology of labour' (Foucault, 2003: 242).

As our working conditions have been transformed over the last three decades through the neoliberal strategies of deindustrialization, financialization, dispersed production regimes, debtfuelled consumption, unemployment, monopoly-rent seeking, etc., there seems to be a sense that those who labour or reproduce in the mode of production are being drawn into 'a nightmare of a different kind, in which the horrors of force, violence, physical coercion and hardship are replaced by the slow suffocation of the spirit, the intellect and the capacity to resist' (Evans, 2004: 52). There are many things at work here, but in terms of the disciplinary technology of labour - those technical ways and means of actually stimulating labour and extracting its product from workers - there is clearly a movement away from the sites and techniques of disciplinary power that so epitomized the industrial society and its apotheosis in the factory, and beyond the orthopaedic disciplinarity of scientific management and its Taylorist principles of microphysical somatic coercion (Hardt, 2008: 8). In short, in the context of advanced or axiomatic capitalism this is a strategic movement in the operations of labour discipline away from the creation of 'docile bodies' and toward that of 'proactive bodies', or perhaps 'proactive souls'.

The task ahead is to ruminate on how the transformation of labour discipline over the last few decades, and the intellectual line taken in governmentality studies, might not turn out to be that sanguine liberation from the constraints of a much maligned disciplinary power claimed by neoliberal apologists (Ewald, 1986: 11; 1991). It is with the moment at which the disciplinary technology becomes constitutive of the society of control that we ought to be concerned, as well as with theorizing the technical and practical actualization of the latter's totalizing logos. This moment can be identified and clinched in a movement from the sovereign's right to 'take life and let live' to a biopolitical imperative of 'let die and make live', a genealogical movement towards a deepening and intensifying mobilization of populations and the 'collective individuals' that constitute them (Foucault, 2007: 42). It is within the population that the governmental form of power takes its 
shape (Pasquino, 1991: 116), but how does it take its shape in, on, and through that object? Pasquino attempted to answer this exact question by reference to 'a whole cluster of practices and knowledges' that is simply corralled under the rubric of 'police' (1991: 116). However, it is through the question of exactly 'by what means' the society of control is introduced - the modality of governmental power predicated in the establishment of populations and their 'collective individuals' that the 'practices and techniques' of the meta-disciplinary is intended to guide us. As this governmental rationality is embedded in strategies and practical techniques (Foucault, 2002d: 416), it is only through analysis of these techniques that the formulation and operation of the society of control and its Polizeiwissenschaft can be grasped.

This movement can perhaps be captured in the figurative (yet strikingly concrete and historical) movement from the prison to the labour camp. It is in the metastasis of the labour camp that the element of meta-disciplinarity can be illuminated, and the emergence of its matrices apprehended. This movement can be discerned in Discipline and Punish, though it is only brought to light through retrospective consideration after assimilating the later lectures on governmentality. For Solzhenitsyn in the Gulag Archipelago (2007) - a work that greatly influenced Foucault's agenda in Discipline and Punish - the labour camp was a matter entirely different from the prison, and at the centre of this difference lies 'the leading idea of the Archipelago - forced labour' (2007b: 10). Camp was thus derived from the motivation 'to get from the camps as much economic profit and production and labour as possible' (2007b: 392-3). Bruno Bettelheim's reflective study on his own experiences in Buchenwald and Dachau led him to conclude that 'to spend time in prison does not produce the character changes described in [camp]' (1943: 446). Quintessentially, the camp was an infinitely more effective 'means of producing changes in the prisoners which will make them more useful subjects of the Nazi state' (Bettelheim, 1943: 419). Here we are dealing with the transformation of individual subjectivities for the purposes of more 'useful' labouring in the biopolitical community. Hold that thought.

Giorgio Agamben has already discussed 'the camp' in juridico-political terms as a quintessentially modern paradoxical structural relation in which homo sacer as the object of sovereign power is formulated via the generalized technique of 'the ban' (Agamben, 1998). I want similarly to mobilize the latent elements of camp to be found in Discipline and Punish in a slightly different direction: camp as a metonym of capitalist government in the society of control constituted by 'meta-disciplinary' techniques. ${ }^{2}$ Camp thus remains that 'nomos of the modern' (Agamben, 1998: 166), but in contrast to Agamben's structuralist anatomy, the 'meta-disciplinary' brings out the physiology of representation and investment. Opposed to the social anatomy of disciplinarity in 'The Prison Industry' (Solzhenitsyn, 2007a), it is the dynamic social physiology of camp 'In Perpetual Motion' (Solzhenitsyn, 2007b), with which we are interested when speaking of the metadisciplinary. Here we get the sense that the techniques of this physiology are not 'nondisciplinary', as Foucault gropingly tried to define $(2003: 39,242)$, but are meta-disciplinary by virtue of their being operative in the rationality of discipline, whilst simultaneously being drawn or vectored out from the modality of discipline by a line-of-flight constitutive of the biopolitical population according to its internal dynamic of imperative accumulation.

The anatomical 'compact prison model' has been an institutional site more or less embodying the rationality of pure disciplinarity, but extending out through the 'carceral continuum' into the social body (Foucault, 1991a: 298-9). Institutionally it is imbricated into those complexes and rationalities that transform the subjectivities of individuals, and that render their bodies docile and inert as part of the process of their social recoding. It is the institutional articulation of that modern modality of power that renders folk 'docile and useful' (1991a: 305), but that usefulness is only a potential usefulness. As I shall argue, the disciplinarity outlined in Discipline and Punish is only a preparatory pedagogic moment of social transformation for the individual 'normalized by compulsion' (1991a: 295), which opens up conditions of possibility and potentiality. 
A problem arises. Prison, and the creation of 'docile bodies' in accord with its disciplinary rationality, is dogged by a fundamental deficiency. This is a technical problem that Solzhenitsyn recognized in the Gulag Archipelago: "“poverty and prison ... give wisdom”. They do. But - where is it to be directed?' (2007b: 602). The prison might well be effective in recoding subjectivities via punitive pedagogy, but it is not productive! ${ }^{3}$ What is the use of punishment here in terms of the social metabolism? It is a type of power that ' $\mathrm{keep}[\mathrm{s}]$ people calm without getting anything positive from them' (Foucault, 2006: 127). Thinking along these lines, Foucault was overhasty at the end of Discipline and Punish when he regarded

the extreme solidity of the prison, that slight invention that was nevertheless decried from the outset. If it had been no more than an instrument of rejection or repression in the service of a state apparatus, it would have been easier to alter its more overt forms or to find a more acceptable substitute for it. (1991a: 305, emphasis added)

The totalitarian regimes of the 20th century were very swift in finding a substitute, and the axiomatic of advanced capitalism has gradually deployed the same logic in substitution for the figurative prison: the camp. What we see in the metamorphosis from prison to labour camp is essentially a modally accretional shift in the technology of labour control from the disciplinary creation of docile bodies to the generation of proactive bodies, from the 'formation of habits' to the 'mobilisation of energy' (Rancière, 2012: 31). Thus Foucault was wrong to state that 'rooted as [prison] was in mechanisms and strategies of power, it could meet any attempt to transform it with a great force of inertia' (1991a: 305). The imperatives of accumulation in axiomatic capitalism are more potent than the rationality of disciplinarity and its historical-institutional 'armatures'.

Looking historically at more concrete and obvious instantiations of camp as institution (Gulag, Nazi labour camps), rather than merely as nomos, logic, rationality, etc., it is not the simple fact that the 'camps' have entailed (forced) labour over the (enforced) leisure or idleness of prison that is important. It is a matter of how labour-power is obtained and deployed, impelled rather than compelled through 'technologies of the self' (Foucault, 2000), through apparatuses that cannot be sufficiently summarized by reference to anatomical disciplinary power. It has been a striking historical feature of the labour camp that bodily confinement and coercion are less characteristic than in the prison setting, and it is in the attempt to address this enigmatic quality in the figurative move from prison to camp that the meta-disciplinary becomes pivotal, and a surprising nostalgic affection for the disciplinary wells up. But what exactly is this meta-disciplinarity?

\section{The Meta-Disciplinary: Unpacking the 'Dovetailing'}

The socio-technological study of the mechanisms of control, grasped at their inception, would have to be categorical and to describe what is already in the process of substitution for the disciplinary sites of enclosure, whose crisis is already proclaimed. (Deleuze, 1992: 7)

We must get beyond the micro-somatic techniques of disciplinarity that have preoccupied so much critical scholarship, and into the so-called 'power at a distance' (Gill, 2014: 22) that is so evident in the more highly developed semio-techniques of what I call 'the meta-disciplinary'. The genealogy of discipline and government is characterized by Foucault not as a step or supersession, but as a 'dovetailing' (Foucault, 2003: 242). To elaborate and explore this 'dovetailing' is to get a handle on the meta-disciplinary.

The meta-disciplinary resides in the tangled genealogical relationship between the rationalities of 'sovereignty', 'discipline', and 'government', and particularly on the threshold between the latter 
two. Let's remember that governmentality, 'governmental rationality', is that 'ensemble formed by institutions, procedures, analyses and reflections, calculations, and tactics' (Foucault, 2007: 108). As a modality of power it both predicates and generates 'population as its target, political economy as its major form of knowledge, and apparatuses of security [physiological regulation] as its essential technical instrument'. Beyond the enclosed sites of a disciplinary power actualized via an anatomic-somatic microphysics, government is a power for which 'population' is the most germane level of life at which its rationality is concerned, and the end for which government itself is conducted as 'police' (Foucault, 2007: 21; 2002d: 416). This is that pastoral modality of power operative in the parametric society of control.

Genealogically this takes us historically from the power of the sovereign, through individuating disciplinary power employed somatically and semiotically in panoptic institutions such as the asylum, prison, barracks and school, to the 'age of security' and 'man-as-species' as the regulated object of this governmental power (Foucault, 2003: 242). This is not a historical narrative, but the way Foucault moves through the modern modalities of power in his corpus over roughly a decade of scholarship. By the time of the lectures the point is that, in contrast to the sovereign's power that characterized the early-modern territorial-fiscal state, a field of activity began to take form in the 18 th century out of the crisis of mercantilism. This field of activity is the 'economy' and sits at the core of the (neo-)liberal problematic: 'how the overall exercise of political power can be modelled on the principles of a market economy' and how 'formal principles of a market economy' can be 'projected on to a general art of government' (Foucault, 2010: 131). Through innumerable discursive jostlings, the intervention of 'government' in the collective life of a 'population' (a categorical invention of modernity) came to redefine the centrality of the modality of sovereign power, and became increasingly the form of political power most relevant to the domain of 'political economy' to which sovereign power was increasingly counterproductive (literally).

In contrast to the pre-modern society of orders and estates, the abstract modern concept of 'population', as the target of government and object of police administration, was born in modernity twin to the individual (Pasquino, 1991: 114). The chiselling out of the individual from a social plane of immanence is not only necessary for a population to exist, but re-enforces its totalizing constellation of relations (Foucault, 2002d: 417). Our individuality in this modality binds us more intimately to the megamachine. The population must be constituted by the creation of individuals, in order for it to be governed and for there to be a field of political economy into and by which government can intervene. There is thus required a mereological establishment of individuals within the population via a particular coding of the social relations between them, that is, the necessary social 'depths and details' (omnes et singulatim) of objectification (Foucault, 1991b: 102). Thus, in a way that is enunciative and accretional, rather than a 'successive unilinear replacement' (Dean, 2003: 117), the role of individuating orthopaedic disciplinary power is retained, augmented, and transfigured, within the new mode of 'government'. This, Foucault made clear in the later elaboration of 'governmentality' found amongst the lectures:

As for discipline ... discipline was never more important or more valorised than at the moment when it became important to manage a population; the managing of a population not only concerns the collective mass of phenomena, the level of its aggregate effects, it also implies the management of population in its depths and its details. (Foucault, 1991b: 101-2; emphasis added)

In the conventional Foucauldian presentation, the decisive change of emphasis in the modality of governmental power here is in the move to ever more effective means of achieving and sustaining the well-being of the population qua population in an entirely non-prescriptive way and without necessary content or definition (Lazzarato, 2015: 109). It is the political reason of the state. 
Table I. Genealogical movement from prison to camp through the meta-disciplinary moment.

\begin{tabular}{ll}
\hline Disciplinarity & Governmentality \\
\cline { 2 - 2 } Prison & Camp \\
\hline Surveillance & Control \\
Formation & Mobilization \\
Space-as-Place & Space-as-Flow \\
Body & Soul \\
Docility & Proactivity \\
Coercion & Mobilization \\
Instruction & Induction \\
Institution & Apparatus \\
Social Anatomy & Social Physiology \\
Topography & Topology \\
Substance & Activity \\
Utility & Profitability \\
Improvement/Correction & Exploitation/Generation \\
Make Die, Let Live & Make Live, Let Die \\
Inaction & Refusal \\
\hline
\end{tabular}

This great transformation in the modalities of power throughout the 19th and 20th centuries means a movement from the sovereign's right 'to take life or let live' to the positive power to "'make" live and "let" die' that characterizes government of the biopolitical population (Foucault, 2003: 241). To the individuating disciplinary power that functions to compel, neutralize, obviate, disable, threaten, render inert, or exclude into 'docility' (passivity and pliancy), must now be added the practical techniques that impel, mobilize, operationalize, tease, blackmail, tempt, or incentivize the instrumental individual within a population, but which nevertheless continue to coerce in some way 'at a distance' and with an averted gaze.

What lies before us then, in the emergence of a meta-disciplinary technology of labour, is a subtle, yet decisive, transition of emphasis from the gaze of discipline through enclosure, and its microphysical technology of coercive force, to the mechanisms of mobilization in the governmental rationality of the biopolitical community. These devices work not by command or instruction, as one might find in the purely disciplinary modality, that is, in the "form of the prohibition "you must not do this"' (Foucault, 2007: 66), nor via the sovereign's 'imposition of a law that says no'. Rather we have a disposition of techniques that inculcate impulsions to achieve, seek reward, gain approval, aspire, succeed, advance, excel, by means of 'representations' generated by the fluidic economy of semio-techniques backed up by particular constellations of material social relations between individuated disciplinary subjectivities in a totalizing biopolitical community. This is the point at which the generalized punishment ceases to be merely an 'art of effects' (Foucault, 1991a: 93) and becomes an art of affects, drawing out the flow of libidinal investments from individuals.

The objection appears (more further down) if we seriously question the progressive narrative of improvement claimed by neoliberals of this pastoral modality of government as some kind of evolution out of the cage of discipline into the sunlit uplands of transparency, possibility, adventure, and the absence of constraint (Ewald, 1986: 11; 1991). ${ }^{4}$ This very outcome seems to have actually been a motivation for Foucault's agenda in governmentality studies: to furnish a more optimistic exploration of power than the depressing doldrums of the disciplinary (Gordon, 1991: 4). Perhaps he was precipitate. Table 1 roughly summarizes the accretional, supplementary, and tangled meta-disciplinary 
movement in the modality of power that translates discipline in terms of government through a 'mutual interpenetration of two strategies' (Dean, 2003: 117) and transports us from 'prison' into 'camp' across the momentary threshold of the meta-disciplinary.

In the governmental rationality, 'technology' is to be understood, derived from techne, as a 'practical rationality governed by a conscious goal' (Foucault, 2002c: 364) - but what conscious goal? It is an increasingly comprehensive and penetrative goal concerned with 'the government of individuals, the government of souls, the government of the self by the self, the government of families, the government of children, and so on' (Foucault, 2002c: 364; Lemke, 2007: 45). Governmental rationality thus entails a new technology of control, which mobilizes the techniques of discipline but which ought not to be characterized as simply 'disciplinary'. As Foucault crucially states, 'this technology of power ... does not exclude disciplinary technology, but it does dovetail into it, integrate it, modify it to some extent, and above all, use it by sort of infiltrating it, embedding itself in existing disciplinary techniques' (Foucault, 2003: 242).

The question we have to ask ourselves is how do we get from the isolated and individuated 'docile' body of pure disciplinarity to the proactive collective individual as part of an economy of beings capable of being governed? How can we start to get a hook into the elusive generality of the society of control and its elementally constitutive moments that emerge as 'metastable states coexisting in one and the same modulation, like a universal system of deformation' (Deleuze, 1992: 5)? These moments are not historically a straightforward product of the disintegrations of the post-Fordist era, it should be born in mind, but have been a latent genealogical vector of modern capitalist rationality throughout.

In terms of the four 'technologies' - matrices of 'practical reason' - that Foucault lays out in 'Technologies of the Self' (2000: 225), the disciplinary techniques are clearly those (1) 'technologies of power' that entail a preparatory 'objectivizing of the subject', and which 'determine the conduct of individuals', but are inadequate as (2) 'technologies of production' that allow us 'to perform, transform, or manipulate things' according to the dynamic imperative of capital accumulation in the social metabolism. It is then by an augmented and perfected (3) 'technology of sign systems', drawn out from the semio-techniques of representation introduced in Discipline and Punish (1991a: 94, 101-3), that the meta-disciplinary is finally realized in full by emergence at the threshold of 'control' in (4) 'technologies of the self', by which individuals are permitted to 'effect by their own means, or with the help of others, a certain number of operations on their own bodies and souls, thoughts, conduct, and way of being, so as to transform themselves' for production (emphasis added). Thus it is only by consideration of all four overlapping and imbricated technologies that a post-disciplinary technology of labour in the society of control can be perceived in terms of a social metabolism. ${ }^{5}$

Meta-disciplinarity is therefore not so much a discretely and coherently different rationality of power itself as it is that augmented dimension of disciplinarity particularly constitutive of the biopolitical community over and through which government is actualized. The meta-disciplinary is then a distinct modality, taking 'modality' as a set of techniques related by an isomorphic line that runs through them. In the political rationality of the society of control it is those specific techniques that are constitutive of the apparatus of police power (Foucault, 2002d: 416). If 'discipline' is that pedagogic and punitive moment of transformation in individual subjectivity, 'meta-discipline' is that moment of introduction of the disciplined subject into the 'useful' productivity of the biopolitical community in terms of a materialist social metabolism that takes the subject beyond 'disciplinary exigencies' (Ewald, 1986: 159-60). It is those species of governmental practices that draw out the subjectivity of the individual from docility to proactivity in the totalizing creation of the biopolitical 'collective individual'.

As with a bourgeois subjectivity, if the disciplined individual subjectivity is still possessed therewith of a transcendent potential, such as in the social solidarity bred of disciplinary 
normalization (Ewald, 1986: 584), and the democratizing negotiation excited by it as a form of knowledge-power (Behrent, 2010: 617), the meta-disciplined 'collective individual' is dispossessed of the same by its instrumental canalization and subordination to the governmental imperatives of the biopolitical community. If 'power' is famously 'an action upon an action', regarding subjectivized objects that are possessed of at least a minimal agential capacity for personal ethical choice and practice (Foucault, 2002b: 340), it could be argued that the violence and coercion of institutionally situated disciplinary power disqualifies it as a form of power (Gordon, 1991: 5). Its technologies would therefore be not those of power at all, but merely a prescriptive force. However, at the risk of ringing out structuralist tones, I argue in the opposite direction. The "condition of possibility' opened up by the creation of disciplined subjectivities, with all its simultaneous deficits and surpluses, insufficient penetrations yet repeated overcodings (Foucault, 1991a: 201), rather opens up a paradoxical interstitial space in which all sorts of evasive and affirmatively countervailing 'practices of the self' can be pursued. This space is then closed, however, in the moment of meta-disciplinarity that canalizes and mobilizes investments under the unitary sign of the biopolitical community and made immediate by the absolute positivity of its totalizing apparatus of techniques in the society of control.

In the example of the prison, figurative and concrete, there has historically been a great intellectual scope for 'moral ascent' through thought and ethically rigorous behaviour such as the refusal (refusing to confess, to inform on others, or by keeping mentally active through calculating the circumference of the Earth!). There has been a space for ethical practice and Enkrateia, which is that modernist Kantian freedom understood as 'intellectual and moral autonomy' (Zaretsky, 2005: 163). Whilst arrival in the zona of camp induces a sense of physical liberation, this is soon dispelled as that space is imploded by the meta-disciplinary techniques that swiftly hijack the subject's 'free' lines of investment and association by means of the governmentality of accumulation. Therefore, it is at this meta-disciplinary moment of closure that our critical attentions, and our strategies of counter-conduct and resistance, ought perhaps to be focused. For it is here that the axiomatic logic of advanced capitalism interpolates and appropriates, and the 'genealogy of capital' returns with a vengeance through the technologies.

Let us consider a couple of instances of meta-disciplinary technique introduced in Discipline and Punish and elsewhere, and that can be drawn out from pure disciplinarity. Firstly, there is malveillance - that 'network of permanent observation' (Foucault, 1991a: 295, emphasis added) that takes the form of a kind of heightened panopticism.

In the Panopticon each person, depending on his place, is watched by all or certain of the others. You have an apparatus of total and circulating mistrust, because there is no absolute point. The perfected form of surveillance consists in a summation of malveillance. (Foucault, 1980: 158)

No longer the lone gaze of the unseen inspector and the denial of any visual horizontality characteristic of the 'axial visibility' of pure disciplinarity (Foucault, 1991a: 200). This networked malveillance could be discerned in the brigade system of Gulag (Solzhenitsyn, 2007b: 156), just as much as in the operations of today's academic rankings and assessment exercises, and serves well as a ligature from pure disciplinary to meta-disciplinary techniques. Camp is not a mere open-air panopticon, it is a society of beings, or rather an economy of beings, in which a new improvised penal 'art of government' has to be established by authority and corresponding 'practices of the self' have to be conjured by those placed under its logic in order to survive, not merely as bodies, but as souls. This is the implicit vision of Foucault's carceral at the end of Discipline and Punish where he introduced in the last few pages a connection of disciplinarity to government by recognizing in the carceral an 'apparatus of punishment that conforms most completely to the new economy 
of power' (1991a: 305). It is the 'power of colonization: putting people to work ... divided into squads and brigades', a kind 'ergotherapy', as in the case of the asylum, distinct from the traditional disciplinary power of 'simple penning' (Foucault, 2006: 127). The movement from the panoptic inspector of the disciplinary to the physiologic 'malveillance' of the collective at least hints at the ligature to government that I claim of meta-disciplinary techniques and practices.

A second exemplary technique is 'limitless postponement' (Deleuze, 1992: 5). In camp this has taken the form of the 'differentiated ration pot' - the distribution of supplementary food amongst the camp labourers conceived with the sole purpose of incentivizing percentages of output above $100 \%$ of the norm (Solzhenitsyn, 2007b: 155). The 'differentiated ration pot' makes clear how the impulsion to labour as a result of limitless postponement of return is immanent to the anatomical structure and physiological systemic relations of the meta-disciplinary technology of labour. For instance, it is limitless postponement of remuneration, promotion, and security of position that incentivizes labourers on the eternally postponed promise of supernormal remuneration. Like the prospect of early release from Gulag based on compliant behaviour, such promises are rarely kept. In fact, they cannot be kept by definition in the regime of differentially enforced scarcity so necessary for primitive accumulations to be possible in the axiomatic of capitalism (Harvey, 1972: 9). However, labour pursuant of 'the big ration', under endlessly postponed conditions of remuneration and security, mines our personal and most intimate dedications and 'eat[s] people alive' (Solzhenitsyn, 2007b: 155): 'in camp it is not the small ration that kills but the big one' (2007b: 208).

Here we see in those techniques generative of the proactive collective individual of the biopolitical community - the augmented malveillance of a refined principle of panopticism and the limitless postponement of the 'differentiated ration pot' - the apparatuses (dispositives) on which government of populations must rest and make its interventions. They take us from a static technology that enforces docility and inertia through coercive enclosure, to a mobilizing horizon of subjectivities amenable to be governed dynamically as epitomized in Discipline and Punish by the carceral.

The carceral makes it possible to carry out the great 'economy' of power whose formula the eighteenth century had sought, when the problem of accumulation and useful administration of men first emerged.

(Foucault, 1991a: 303)

Discipline and Punish introduces the apparatuses of 'semio-techniques' (1991a: 128-31), which are the basis for the more material meta-disciplinary techniques and that contrast paradoxically with the complex of orthopaedic microphysics that has dominated the scholarship. After Discipline and Punish there seems to be a movement in critical thinking away from the 'representations of signs' and the 'punitive city' towards a greater emphasis on the somatic techniques of coercion and a centring of 'the body' in both Foucault's work and the subsequent industry of Foucauldian studies. Meta-disciplinary apparatuses operate through those inductive 'representations' that draw on the dynamic potential of the semio-technical complex of representations more than on the micro-political technologies of somatic coercion that remain closer to the plane of the purely disciplinary.

\section{A Governable Subjectivity for Capital}

From where does the dynamism essential to the continued existence of the biopolitical community come - a biopolitical community that must ontologically be dynamic? In order to grasp fully the meta-disciplinary transfigurations discussed so far, the imperative logic that drives these practices, 
and their recurrent emergence in historical time, must be identified. There is an historical asymmetry here that belies any claim to an internally undifferentiated and normative governmentality of life in the biopolitical community as an autonomous sphere of action or homeostatic 'police' entity. There is a fundamental spatio-temporal motor at work here, driving the individuating function of the meta-disciplinary and its mereological apparatuses in a given population, and a logic that entails the figurative and real asymmetric destruction of lives in that biopolitical multiplicity in the furtherance and successful continuity of Life. That something is axiomatic capitalism. ${ }^{6}$ This is an end to which individuals, in this case 'collective individuals', are 'simply instrumental' in the final analysis (Foucault, 2007: 42).

Since the state is its own finality, and since the governments must have for an exclusive aim not only the conservation but also the permanent reinforcement and development of the state's strengths, it is clear that the governments don't have to worry about individuals ... the individual becomes pertinent for the state insofar as he can do something for the strength of the state. (Foucault, 2002d: 406)

The rationality of this 'political marginalization' of the individual is of a crucially ambiguous sort that requires it 'to live, to work, to produce, to consume; and sometimes what he has to do is to die' (2002d: 406). The normative conceptualization of the biopolitical population usually exploited from the lectures presents us with a dubiously homeostatic entity that is symmetrical in its totality. It is insufficient (and arguably even reactionary) to suppose a teleological regulation of life in the biopolitical community toward the abstract maintenance of Life itself and the simple reproduction of population. This would just be an unstriated plane of consistency, without any dynamic structure or 'lines of stratification' (Deleuze and Guattari, 2013: 22), denying us any analytical insight into what is happening spatio-temporally. In the governmental rationality, capital is inscribed as a stratum-generating 'tracing' on the body-without-organs, ${ }^{7}$ if you will, a phenomenon of accumulation and extraction of useful labour (Deleuze and Guattari, 2013: 184), marking spatially and generating historically the particularities of its concrete operations. This is capitalist governmentality.

If discipline be the mode, this then is the motor that drives the individuating function and the creation of multiplicity from the unity of the biopolitical population. What establishes the barriers, differentials, membranes, and penumbrae that constitute the 'depths and details' internal to the biopolitical population as a whole? This can be accounted for by the insertion of a capitalist imperative of accumulation that establishes the particular and asymmetric mereonomic configuration of identity and difference necessary to generate and regenerate the internal dynamic infrastructure of the biopolitical population, and its necessarily differential flows. It is the logic of axiomatic capitalism that furnishes the idiomatic 'depths and details' by which particularity is chiselled out of generality, and by which 'collective individuals' are marked out as 'cases' (Foucault, 1991a: 191-2), and without which there would be no dynamism or perpetual motion in the biopolitical population. Capitalist logic motivates the dynamic internal structuring of biopolitical government and drives its perpetual thirst for ever-more production and growth.

The problem of biopolitical government as it seems to confront us arises when the political reason behind the 'individuating power' is not that of the pastoral deity and its 'final kindness' (Foucault, 2002a: 300, 302) but that of capital and the final indifference of its spatio-temporal imperatives of perpetual accumulation. This leaves us with a decisive critique of governmentality as entailing a sacrificial abandonment of the individual, or rather categories of individuals, in accord with the political reason of the biopolitical community determined concretely by the dynamics of capital accumulation and its genealogical autopoetic generation of meta-disciplinary techniques toward this end. 
The practical implications of these meta-disciplinary techniques are that resistances and counter-conducts must wrestle with a proactivating power. This will necessitate tactical and strategic resistances of a different kind to those required in the idiom of pure disciplinarity, and that are supposedly not even required in the autonomous sphere of governmentality. We can see how the relative ineffectiveness of disciplinarity as a modality of power lies in the surplus entailed in the activity of that power as realized through its techniques (Foucault, 1991a: 201). Resistance is engendered by this power itself in its operation and realization. Disciplinary power entails a surplus that engenders its own counter-conduct, just as the threat to sovereignty is created in the spectacle of public punishment out of its own reflexive challenge in the spectacular judicial act itself of sovereign power exercised on the body of the condemned (1991a: 73).

However, in 'the camp' we see how any such surplus is swiftly appropriated, redirected, and channelled into productive activity, and the private, disputational, or insurrectional moment of surplus annihilated. The relative effectiveness of the meta-disciplinary in capitalist governmentality stems from the apparent absence of such a surplus in this modality. As such, resistance to power cannot rely upon the surplus of disciplinary power to provoke or establish the terms of resistance. A modality of power predicated on 'proactivity' must be met with a resistance characterized by a heightened sensitivity that takes the initiative and creates the conditions of possibility for its own practices of counter-conduct.

In the meta-disciplinary idiom, the materialist 'soul' is still the target of techniques as a 'correlative of a certain technology of power over the body' (Foucault, 1991a: 29-30). However, it is also produced 'in a more general way' as 'the element in which are articulated the effects of a certain type of power' (1991a: 29), a power that derives from the complex of semio-techniques and their 'representations' (1991a: 101-2). It is a soul that is both 'effect and instrument of a political anatomy', and political physiology, that also imprisons the body through which is it reached. But this meta-discipline projects not those disciplinary representations that strike individuals into inaction and malleable passivity; they are of a different kind that place individuals into more intimate material and social relations 'at a distance', drawing out and recording productive libidinal investments.

The interiorization of the mechanisms of power through disciplinary micro-physical techniques is therefore merely the first movement of control that secures the "collaboration of the Self' in a modality of power 'diffused and decentred through the social body' (Federici, 2004: 149). The discipline of enclosure seems then to be a preparatory and pedagogical moment of subjective transfiguration on the way to the modern 'self-management' that epitomizes bourgeois subjectivity (Federici, 2004: 149). It could be argued then that, in contrast to the enclosures of disciplinary power, this movement toward the open economy of camp opens up a space of autonomous personal agency. However, such would be to reckon without the accumulation imperatives of capitalist social relations, which render the realization of this subjectivity perpetually imperfect through dynamically structural asymmetries and the canalisations of their generative lines-of-flight. The meta-disciplinary moment emerges so as to draw out and augment the techniques of disciplinarity in the forging of more 'governable' individuals, but certainly not more emancipated individuals, under the suasions of a capitalist logos. It is only by the analytic reinsertion of a capitalist dynamic into the mode of governmentality, something that comes to light only after reading the lectures on governmentality and then returning to Discipline and Punish, that the meta-disciplinary can be discerned as a dimension of the disciplinary in Discipline and Punish and other writings.

This is a reformulation of the industrial pathology of capitalism that forces the individual to internalize the productive apparatus, moulding the worker's personality and subjectivity for purposes of command and organization (Virno and Hardt, 1996: 133), resulting in 'inner immigration' 
and self-exploitation (Lorenz, 2012: 620), and the territorialized hijacking of a personal libidinal economy subjectivized. One recalls in this capitalist pathology Marx's 'manufacturing moment' that 'converts the worker into a crippled monstrosity by furthering his particular skill as in a forcing-house, through the suppression of a whole world of productive drives and inclinations' (Marx, 1990: 481). However, it is not so much a suppression with which we must now reckon as it is a formidable mobilization.

The original panopticon of Bentham was conceived on a utilitarian, though retrospectively chilling, Enlightenment principle of improvement. The apparatuses of capitalist governmentality in the society of control have no such imperative necessarily, and as the memory of the disciplinary fades, it is plausible that a 'nightmare of a new kind' will increasingly dominate - a biopolitical community of expendable 'collective individuals' who, if in refusal will not be 'made live', will rather be 'let die'.

Such being the case, as prelude to any statement or formulation of 'practices of resistance' regarding meta-disciplinary techniques, we must at least (and maybe at most) identify and elaborate the practices of control and the idiomatic operative logic by which they are realized. We must target those meta-disciplinary sutures that mobilize a transformative pedagogical disciplinary moment for the governmental rationality of a police power driven by the asymmetric spatio-temporal imperatives of capital accumulation, and introject our critical energies there.

That is what this paper has attempted, taking the first step toward those practices of resistance which each must determine for themselves. The matter begins with the personal ethical practice of the individual. To resist the consigning, placing, and canalizing forces of proactivation in the techniques of meta-disciplinarity that blackmail us intimately from a distance, it is the manifest and exemplary refusal of individuals to play ball, rather than active resistance, that is likely most effective. To meet proactivating power as though it were the exercise of sovereign or disciplinary power that produces its own surplus of provocation is ultimately self-defeating given the suffocating, yet mobile and adaptable, meta-disciplinary and governmental 'power at a distance'.

\section{Conclusion}

So what is the bearing of the meta-disciplinary in the context of this critique of governmentality? How does the identification of a moment of decisively meta-disciplinary techniques supply us with inspiration for appropriate counter-conduct in the technology of labour control? If 'power ipso facto implies resistance, while acts of resistance always draw upon the power relations in which they are embedded' (Behrent, 2010: 603), it is also true that this resistance cannot be homologous to the action of that power. Following this, it seems that both sovereign and disciplinary power engender particular surpluses of power (Foucault, 1991a: 201), the former as 'challenge' and the latter as 'over-coding'. The sovereign subject revolts at the spectacle of the sovereign's revenge, and seeks the head of the king. The coercions of disciplinary power and its enclosed institutions can only be resisted by the physical or figurative 'escape' (the truanting pupil, the AWOL patient, the prison fugitive, the army deserter, the uncooperative psycho-analysant). These respective strategies of counter-conducted resistance will be ineffective in the meta-disciplinary moment on the threshold of the society of control. 'Rebellion' is crushed or canalized and 'escape' offers merely a flight into the totalized zone of biopolitical ban and living death. Identification of the distinctly meta-disciplinary moment can possibly lead us to more germane and hence efficacious counterconducts. Foremost amongst these strategies is the 'refusal': a cunning tendency towards 'inertia'; a tactical resistance to being mobilized and productive; stubbornly clinging to one's place in the tent, but refusing to relieve oneself. 


\section{Acknowledgements}

This article is based on a paper presented at the conference 'Time Served: Discipline and Punish 40 Years On', Nottingham Trent University, Nottingham Galleries of Justice, 11-12 September 2015. The feedback, comments, and the conference in general were very helpful and constructive, not to mention enjoyable. My participation was made possible by the efforts of Sophie Fuggle, and other organizers at Notts Trent, in securing the participation fee waiver for all involved.

\section{Funding}

This research received no specific grant from any funding agency in the public, commercial, or not-for-profit sectors.

\section{Notes}

1. There is a justification for the prefatory 'meta', which will become clear below. It is not simply the creation of an intellectual commodity by the time-honoured addition of a Greco-Latin prefix, though it never hurts.

2. Perhaps the camp, and its operative logic as a 'peculiarly modern phenomenon' (Poulantzas, 2014: 107), could be treated as a rhizomatically established plateau of its own in the juggled schizophrenia of axiomatic capitalism.

3. 'The same could be said about Taylorism. The system of Taylorism was an extraordinary invention by an engineer who wanted to combat laziness and everything that slows down production. But one can still ask: did Taylorism ever really work?' (Foucault, 1980: 162).

4. The sanguine view that Francois Ewald presents of insurance, as a liberating apparatus that makes a productive opportunity out of risk hitherto treated as a mere obstacle to activity, is a good example of this. Such arguments could be made generally of capitalism; after all, it gets us doing things! It is as though after assimilating the first half of The Communist Manifesto on the wonders of capitalism's energy and productivity, one forgets the concomitant exploitations and endless structural asymmetries of The Working Day. It is as though worker and capitalist reside equally under an internally symmetrical and autonomous governmentality of the population.

5. It should now be clear why the prefix 'meta-' is preferable to 'post-' regarding discipline. Discipline is not left behind, but transfigured.

6. Axiomatic capitalism ought to be taken as something total, but not exhaustive, and something that touches everything, but that does not account for everything. This is not an operation that makes 'historical capitalism ... deducible as the only possible and necessary figure of the logic of capital' (Foucault, 2010: 165), but offers a given historical capitalism as a singularity with its own conditions of possibility. It is important to lay this out even briefly, in order at least to make the apostolic obsessives pause long enough in their denunciations to realize that today's more protean Marxist thinking can be as ontoepistemologically sensitive as all-too-often they complacently assume themselves to be.

7. The body-without-organs alludes to 'a substrate that is also identified as the plane of consistency. It is a 'non-formed, non-organized, non-stratified or destratified body or term' and is 'opposed to the organizing principles that structure, define and speak on behalf of the collective assemblage of organs, experiences or states of being' (Message, 2010: 37-8).

\section{References}

Agamben G (1998) Homo Sacer: Sovereign Power and Bare Life. Stanford, CA: Stanford University Press.

Behrent MC (2010) Accidents happen: Francois Ewald, the 'anti-revolutionary' Foucault, and the intellectual politics of the French welfare state. The Journal of Modern History 82: 585-624.

Bettelheim B (1943) Individual and mass behaviour in extreme situations. Journal of Abnormal and Social Psychology 38(5): 417-452.

Dean M (2003) Empire and government. Distinktion: Scandinavian Journal of Social Theory 4(1): 111-122.

Deleuze G (1992) Postscript on the societies of control. October 59: 3-7. 
Deleuze G and Guattari F (2013) A Thousand Plateaus: Capitalism and Schizophrenia. London: Bloomsbury.

Evans M (2004) Killing Thinking: The Death of the Universities. London: Continuum.

Ewald F (1986) L'état providence. Paris: Grasset.

Ewald F (1991) Insurance and risk. In: Burchell G, Gordon C and Miller P (eds) The Foucault Effect: Studies in Governmentality. Chicago, IL: University of Chicago Press, 197-210.

Federici S (2004) Caliban and the Witch: Women, the Body and Primitive Accumulation. Brooklyn, NY: Autonomedia.

Foucault M (1980) Power/Knowledge: Selected Interviews and Other Writings, 1972-1977. New York, NY: Pantheon Books.

Foucault M (1991a) Discipline and Punish: The Birth of the Prison. London: Penguin.

Foucault M (1991b) Governmentality. In: Burchell G, Gordon C and Miller P (eds) The Foucault Effect: Studies in Governmentality. Chicago, IL: University of Chicago Press, 87-104.

Foucault M (2000) Technologies of the self. In: Rabinow P (ed.) Essential Works of Foucault, 1954-1984, Vol. 1: Ethics. London: Penguin, 223-251.

Foucault M (2002a) 'Omnes et Singulatim': Toward a critique of political reason. In: Faubion J (ed.) Essential Works of Foucault, 1954-1984, Vol. 3: Power. London: Penguin, 298-325.

Foucault M (2002b) The subject and power. In: Faubion J (ed.) Essential Works of Foucault, 1954-1984, Vol. 3: Power. London: Penguin, 326-348.

Foucault M (2002c) Space, knowledge, and power. In: Faubion J (ed.) Essential Works of Foucault, 19541984, Vol. 3: Power. London: Penguin, 349-364.

Foucault M (2002d) The political technology of individuals. In: Faubion J (ed.) Essential Works of Foucault, 1954-1984, Vol. 3: Power. London: Penguin, 403-417.

Foucault M (2003) Society Must Be Defended: Lectures at the Collège de France 1975-1976. Basingstoke: Macmillan.

Foucault M (2006) Psychiatric Power: Lectures at the Collège de France 1973-1974. Basingstoke: Palgrave Macmillan.

Foucault M (2007) Security, Territory, Population: Lectures at the Collège de France, 1977-78. Basingstoke: Palgrave Macmillan.

Foucault M (2010) The Birth of Biopolitics: Lectures at the Collège de France, 1978-1979. Basingstoke: Palgrave Macmillan.

Gill R (2014) Academics, cultural workers and critical labour studies. Journal of Cultural Economy 7(1): $12-30$.

Gordon C (1991) Governmental rationality: An introduction. In: Burchell G, Gordon C and Miller P (eds) The Foucault Effect: Studies in Governmentality. Chicago, IL: University of Chicago Press, 1-51.

Hardt M (2008) Introduction: Labour at work. In: Marazzi C (ed.) Capital and Language: From the New Economy to the War Economy. Los Angeles, CA: Semiotext(e), 7-11.

Harvey D (1972) Revolutionary and counter revolutionary theory in geography and the problem of ghetto formation. Antipode 4(2): 1-13.

Lazzarato M (2015) Governing by Debt. Los Angeles, CA: Semiotext(e).

Lemke T (2007) An indigestible meal? Foucault, governmentality and state theory. Distinktion: Scandinavian Journal of Social Theory 15(1): 43-64.

Lorenz C (2012) If you're so smart, why are you under surveillance? Universities, neoliberalism and new public management. Critical Inquiry 38(3): 599-629.

Marx K (1990) Capital, Vol. 1. London: Penguin.

Message K (2010) Body without organs. In: Parr A (ed.) The Deleuze Dictionary. Edinburgh: Edinburgh University Press, 37-39.

New Formations (2014) Societies of control: Call for contributions. Available (consulted 1 December 2015) at: http://www.lwbooks.co.uk/journals/newformations/issue/nf8485.html.

Pasquino P (1991) Theatrum politicum: The genealogy of capital - police and the state of prosperity. In: Burchell G, Gordon C and Miller P (eds) The Foucault Effect: Studies in Governmentality. Chicago, IL: University of Chicago Press, 105-118. 
Pasquino P (1993) Political theory of war and peace: Foucault and the history of modern political theory. Economy and Society 22(1): 77-88.

Poulantzas N (2014) State, Power, Socialism. London: Verso.

Rancière J (2012) The Intellectual and His People: Staging the People, Vol. 2. London: Verso.

Skinner Q (2002) Meaning and understanding in the history of ideas. In: Skinner Q (ed.) Visions of Politics, Vol. 1: Regarding Method. Cambridge: Cambridge University Press, 57-89.

Solzhenitsyn A (2007a) The Gulag Archipelago, 1918-1956, Vol. 1. New York, NY: Harper Perennial.

Solzhenitsyn A (2007b) The Gulag Archipelago, 1918-1956, Vol. 2. New York, NY: Harper Perennial.

Virno P and Hardt M (1996) Radical Thought in Italy: A Potential Politics. Minneapolis, MI: University of Minnesota Press.

Zaretsky E (2005) Secrets of the Soul: A Social and Cultural History of Psychoanalysis. New York, NY: Vintage Books. 